ELIZA WAJDA

Akademia Pedagogiczna, Kraków

\title{
Proces ksztaltowania się Motoroli jako firmy ponadnarodowej
}

\begin{abstract}
Postępujący proces globalizacji w podstawowym stopniu wpływa na intensyfikację rozwoju cywilizacyjnego i zmian dokonujących się w świecie, na poszczególnych kontynentach, w państwach i regionach. Głównymi podmiotami, które bezpośrednio intensyfikują ten proces są korporacje transnarodowe. Jak przyjmuje A. Zorska (2000), posiadają one duży potencjał oraz mają zdolności integrowania i koordynowania wielkich systemów produkcyjnych, usługowych i finansowych.

Wielkie przedsiębiorstwa przemysłowe zaczęły się kształtować już w XIX w. i były konsekwencją zrodzonej w XVIII w. rewolucji przemysłowej, rozpoczynającej proces koncentracji produkcji i kapitału. W pierwszej połowie XIX w. pojawiły się pierwsze formy działalności międzynarodowej przejawiające się wywozem kapitału (Sporek 1998). Proces ten intensyfikowały m.in. szybki wzrost potencjału produkcyjnego i kapitałowego przedsiębiorstw przemysłowych, a także postęp naukowo-badawczy i organizacyjny. Dla rozwoju działalności produkcyjnej i poszukiwania nowych rynków zbytu przedsiębiorstwa te zaczęły stopniowo podejmować działania na rzecz zdobywania nowych rynków zagranicznych (Zorska 1996). Pod koniec XIX w. nasila się zjawisko koncentracji produkcji poprzez dobrowolne umowy zawierane między konkurującymi dotychczas przedsiębiorstwami.

W pierwszym dziesięcioleciu XX w. zaczęły powstawać porozumienia ponadnarodowe, których celem było podporządkowanie sobie rynków krajów słabiej rozwiniętych gospodarczo. Narastające jednak antagonizmy między mocarstwami doprowadziły do ograniczenia międzynarodowych kontaktów handlowych a także produkcyjnych. Pierwsza wojna światowa przekreśliła podejmowane przez korporacje ekspansje. W okresie dwudziestolecia międzywojennego nadal utrzymuje się wrogość między krajami europejskimi. Jedynie Stany Zjednoczone, wzmocnione przemysłowo i kapitałowo po I wojnie światowej, podjęły ekspansję na rynki innych kontynentów (Wojciechowski 2000). Nowoczesne struktury produkcyjno-organizacyjne i kapitałowe korporacji transnarodowych szczególnie intensywnie rozwijają się w okresie powojennym. Szczególne nasilanie się procesów koncentracji kapitałowej rozpoczęło się w latach 20. wraz z rozwojem działalności produkcyjnej w coraz to większych firmach i tworzeniem coraz bardziej złożonych form koncentracji kapitału. $\mathrm{Na}$ początku lat 60 . dominację na rynku globalnym obejmują przedsiębiorstwa
\end{abstract}


amerykańskie. Następnie pojawiają się korporacje Europy Zachodniej i Japonii. Stopniowo ulega zmianie zarówno struktura korporacji, jak i strategia ich działania (Sporek 1998).

tab. 1 
Tabela 2. Potencjał korporacji telekomunikacyjnych wg państw w 2002 r.

\begin{tabular}{|c|c|c|c|c|c|}
\hline \multirow[b]{2}{*}{ Państwo } & \multirow[b]{2}{*}{$\begin{array}{l}\text { Liczba } \\
\text { firm }\end{array}$} & \multirow{2}{*}{$\begin{array}{l}\text { Wartość } \\
\text { rynkowa } \\
\text { w mld \$ }\end{array}$} & \multirow[b]{2}{*}{$\begin{array}{l}\text { Sprzedaż } \\
\text { w mln \$ }\end{array}$} & \multicolumn{2}{|c|}{ Struktura } \\
\hline & & & & $\begin{array}{l}\text { wartości } \\
\text { rynkowej }\end{array}$ & sprzedaży \\
\hline Stany Zjednoczone & 5 & 372899 & 219782 & 28,6 & 24,6 \\
\hline Japonia & 4 & 235153 & 172363 & 18,0 & 19,3 \\
\hline Wielka Brytania & 4 & 151214 & 69947 & 11,6 & 7,8 \\
\hline Niemcy & 2 & 101244 & 126413 & 7,8 & 14,2 \\
\hline Włochy & 3 & 99922 & 68279 & 7,7 & 7,7 \\
\hline Hiszpania & 2 & 78218 & 36980 & 6,0 & 4,1 \\
\hline Finlandia & 2 & 71875 & 31183 & 5,5 & 3,5 \\
\hline Francja & 3 & 47093 & 83010 & 3,6 & 9,3 \\
\hline Australia & 1 & 34449 & 13068 & 2,6 & 1,5 \\
\hline Szwajcaria & 1 & 18970 & 9182 & 1,5 & 1,0 \\
\hline Singapur & 1 & 15662 & 2756 & 1,2 & 0,3 \\
\hline Kanada & 1 & 14996 & 14209 & 1,1 & 1,6 \\
\hline Holandia & 1 & 10938 & 10962 & 0,8 & 1,2 \\
\hline Portugalia & 1 & 9140 & 5350 & 0,7 & 0,6 \\
\hline Grecja & 1 & 8137 & 3358 & 0,6 & 0,4 \\
\hline Szwecja & 1 & 7612 & 5873 & 0,6 & 0,7 \\
\hline Norwegia & 1 & 6862 & 5068 & 0,5 & 0,6 \\
\hline Hongkong & 1 & 5659 & 2815 & 0,4 & 0,3 \\
\hline Dania & 1 & 5628 & 6482 & 0,4 & 0,7 \\
\hline Nowa Zelandia & 1 & 4588 & 2699 & 0,4 & 0,3 \\
\hline Austria & 1 & 4321 & 2485 & 0,3 & 0,3 \\
\hline Razem & 38 & 1304580 & 892264 & 100 & 100 \\
\hline
\end{tabular}

Źródło: Tabela 1

Tabela 3. Potencjał korporacji telekomunikacyjnych wg kontynentów w 2002 r

\begin{tabular}{|c|c|c|c|c|c|c|c|}
\hline \multirow[b]{2}{*}{ Kontynent } & \multirow[b]{2}{*}{$\begin{array}{l}\text { Liczba } \\
\text { firm }\end{array}$} & \multirow[b]{2}{*}{$\begin{array}{l}\text { Wartość } \\
\text { rynkowa }\end{array}$} & \multirow[b]{2}{*}{ Sprzedaż } & \multicolumn{2}{|c|}{ Struktura } & \multirow{2}{*}{$\begin{array}{l}\text { Wartość } \\
\text { rynkowa } \\
\text { firm do } \\
\text { pozycji } 100\end{array}$} & \multirow{2}{*}{\begin{tabular}{|c|} 
Struktura \\
wartości \\
rynkowej \\
firm \\
do 100. \\
miejsca
\end{tabular}} \\
\hline & & & & $\begin{array}{l}\text { wartość } \\
\text { rynkowa }\end{array}$ & sprzedaż & & \\
\hline \begin{tabular}{|l|} 
Ameryka \\
Północna
\end{tabular} & 6 & 387892 & 233991 & 29,7 & 26,2 & 336596 & 86,8 \\
\hline Europa & 23 & 651295 & 464572 & 49,9 & 52,1 & 376591 & 57,8 \\
\hline $\begin{array}{l}\text { Australia } \\
\text { i Nowa Zelandia }\end{array}$ & 2 & 8919 & 15767 & 0,7 & 1,8 & 0 & 0 \\
\hline
\end{tabular}




\begin{tabular}{|l|r|r|r|r|r|r|r|}
\hline Azja & 6 & 256474 & 177934 & 19,6 & 19,96 & 209571 & 81,7 \\
\hline Razem & & 1304580 & 892264 & 100 & 100 & 922758 & \\
\hline
\end{tabular}

\section{Źródło: Tabela 1}

Największe korporacje transnarodowe są organizacjami gospodarczymi, których obroty często przekraczają PKB wielu krajów. I tak dla porównania w 1998 r. dla Łotwy, Estonii, Litwy czy Słowacji wartość PKB była niższa niż 10 mld \$ (Mydel 2000), podczas gdy w roku 1997 obroty korporacji Nippon Tel \& Tel wyniosły 71,1 mld \$ (czyli były 7-krotnie większe od obrotów tych krajów), a Motoroli 29,8 mld \$.

Ponad $1 / 3$ z pięciuset największych korporacji świata to organizacje amerykańskie, a przynależność ich jest ustalana poprzez miejsce zarejestrowania firmy-matki (Dytwald 1997). W 1970 r. w 14 krajach wysoko rozwiniętych miało swoją siedzibę ok. 7 tys. korporacji ponadnarodowych. W roku 1990 ich liczba wzrosła już do 24 tys. a w trzy lata później do 38 tys., czyli w 23-letnim okresie liczba korporacji wzrosła 5-krotnie. Obecnie prawie połowa korporacji ponadnarodowych ma swoją siedzibę macierzystą w pięciu najbardziej rozwiniętych gospodarczo krajach, tj. Stanach Zjednoczonych, Japonii, Francji, Niemczech, Wielkiej Brytanii (Gwiazda 1998). Korporacje ponadnarodowe są tymi organizacjami, które nadają tempo światowej gospodarce, poprzez eksperymentowanie z nowymi ideami czy prowadzenie badań pilotażowych.

Z powyższych przesłanek wyłania się potrzeba prowadzenia i systematycznego pogłębiania badań nad procesem kształtowania się korporacji ponadnarodowych jako wiodących ogniw wzrostu gospodarczego i cywilizacyjnego. Do tego nurtu badawczego nawiązuje niniejsza analiza, której przedmiotem jest proces kształtowania się jednej z korporacji trans-narodowych - Motoroli. Firma ta reprezentuje nowoczesny koncern branży telekomunikacyjnej oparty na produktach wysokich technologii. Należy ona do czołówki światowych korporacji przemysłowych. W 2002 roku zajmowała lokatę 108 wśród 1000 wiodących firm światowych (tab.1), natomiast w rankingu 50 największych światowych firm pierwsze miejsce zajmowała japońska firma Nippon Telegraph \& Telephone (Zioło 2001).

Wartość rynkowa 38 firm telekomunikacyjnych w 2002 roku stanowiła 7,1\% wartości wszystkich firm wyszczególnionych w rankingu "Global 1000”. Wśród 38 firm telekomunikacyjnych 23 to firmy europejskie (co stanowi 60\%), 6 firm pochodziło z Ameryki Północnej oraz Azji. Najwięcej firm telekomunikacyjnych wyróżnionych w tym rankingu, bo aż 5, pochodzi ze Stanów Zjednoczonych (tab. 2), a ich wartość stanowi 28,6\%; po 4 duże firmy telekomunikacyjne posiadają Japonia $(18,0 \%)$ i Wielka Brytania $(11,6 \%)$. Warto jednak zwrócić uwagę, że aż 86,8\% telekomunikacyjnych firm amerykańskich znajdujących się na liście "Global 1000" to firmy, które ulokowały się w pierwszej setce, podobnie jak firmy azjatyckie (tab. 3). Natomiast w pierwszej setce znalazło się tylko 57,8\% firm europejskich. Z powyższej analizy można już zauważyć pewne centra lokalizacji najlepszych firm ponadnarodowych.

\section{PROCES KSZTAŁTOWANIA SIĘ MOTOROLI}

Do ogólnych reguł rozwoju korporacji nawiązuje także proces kształtowania się Motoroli, która rozwijała się od małej firmy do firmy ponadnarodowej. Powstanie tej firmy 
sięga 25 września 1928 r., kiedy to Paul V. Galvin wraz z bratem Josephem E. Galvinem założyli

w Stanach Zjednoczonych w Chicago firmę "The Galvin Manufacturing Corporation", która początkowo zatrudniała tylko 5 osób. Pierwszym produktem firmy był akumulator samochodowy. Szybki rozwój firmy związany był z intensywnie rozwijającą się produkcją samochodów. Po pierwszym roku działalności wartość sprzedaży firmy wyniosła 63 tys. \$, a w 1930 sprzedaż produktów wzrosła do 287 tys. \$, tj. prawie 4,5-krotnie.

Firma nadal nawiązywała do potrzeb rozwoju przemysłu samochodowego oraz zaproponowała nowy dla niego produkt, jakim było radio samochodowe - model 5T71, któremu nadano nazwę Motorola. Od tego czasu firma jest rozpoznawalna pod nazwa Motorola. Kolejnym produktem Motoroli stają się domowe radiootwarzacze. Jednak podstawowym czynnikiem tempa wzrostu Motoroli było intensywne tempo rozwoju przemysłu samochodowego i rosnące zapotrzebowanie na radioodbiorniki. Wskazuje na to fakt, iż w okresie pierwszych 12 lat funkcjonowania firmy (1928-1940) zatrudnienie zwiększyło się z 5 osób do 985, a sprzedaż netto z 63 tys. \$ do 9,94 mln \$, czyli wzrosło 1577 razy. W celu podniesienia konkurencyjności produktów i opanowywania nowych rynków znaczny nacisk położono na rozszerzenie asortymentu produkcyjnego.

Tabela 4. Zmiany sprzedaży i zatrudnienia w Motoroli w latach 1940-2001

\begin{tabular}{|c|c|c|c|c|}
\hline Lata & Zatrudnienie & $\begin{array}{c}\text { Sprzedaż netto } \\
\text { w mln } \$\end{array}$ & $\begin{array}{c}\text { Dynamika } \\
\text { zatrudnienia }\end{array}$ & $\begin{array}{c}\text { Dynamika } \\
\text { sprzedaży }\end{array}$ \\
\hline 1940 & 985 & 9,9 & 0,9 & 0,1 \\
\hline 1950 & 9325 & 117,1 & 8,9 & 1,1 \\
\hline 1960 & 14740 & 229,1 & 14,0 & 2,0 \\
\hline 1970 & 36000 & 796,4 & 34,3 & 7,3 \\
\hline 1980 & 71500 & 3100 & 68,1 & 28,5 \\
\hline 1990 & 105000 & 10890 & 100,0 & 100,0 \\
\hline 2000 & 147000 & 37580 & 140,0 & 345,1 \\
\hline 2001 & 111000 & 30004 & 105,7 & 275,5 \\
\hline
\end{tabular}

Źródło: Obliczenia własne na podstawie danych ze strony internetowej www.motorola.com

Firma wykorzystała istniejącą lukę na rynku, rozpoczynając w 1941 r. produkcję odbiornika radiowego dla ludności i oferując pierwszą komercyjną linię radia z dwuzakresowym systemem FM.

Kolejnym etapem rozwoju asortymentu było uruchomienie w 1943 r. produkcji przenośnego plecakowego dwupasmowego radioodtwarzacza SCR300 dla wojska, znanego jako "walkie-talkie". Ważył on zaledwie 35 funtów i miał zasięg od 10 do 20 mil. Dalszym ważnym czynnikiem rozwoju firmy stało się rozpoczęcie własnych prac badawczych mających na celu unowocześnianie produkcji. W wyniku tych działań w 1947 r. wprowadzono do produkcji odbiornik telewizyjny, model VT71, który szybko zdobył rynki zbytu. W pierwszym roku sprzedano ponad 100 tys. tych odbiorników.

$\mathrm{Na}$ dalszy rozwój firmy w znacznym stopniu wpływały powiązania $\mathrm{z}$ dominującymi wówczas firmami samochodowymi, jak Ford Motor Company i Chrysler Corporation. 
W wyniku rozwoju produkcji oraz w celu obniżania jej kosztów Motorola jako pierwsza firma na świecie przenosi swoje fabryki instalacyjne poza obręb Chicago. W 1949 r. w Phoenix w Arizonie Motorola uruchamia produkcję półprzewodników. Procesowi temu towarzyszy poważny wzrost zatrudnienia i wartości sprzedaży (tab. 4, ryc. 1, 2). W latach 1940-1950 sprzedaż wzrosła z 9,94 mln \$ do $117 \mathrm{mln}$ \$, czyli prawie 12-krotnie.

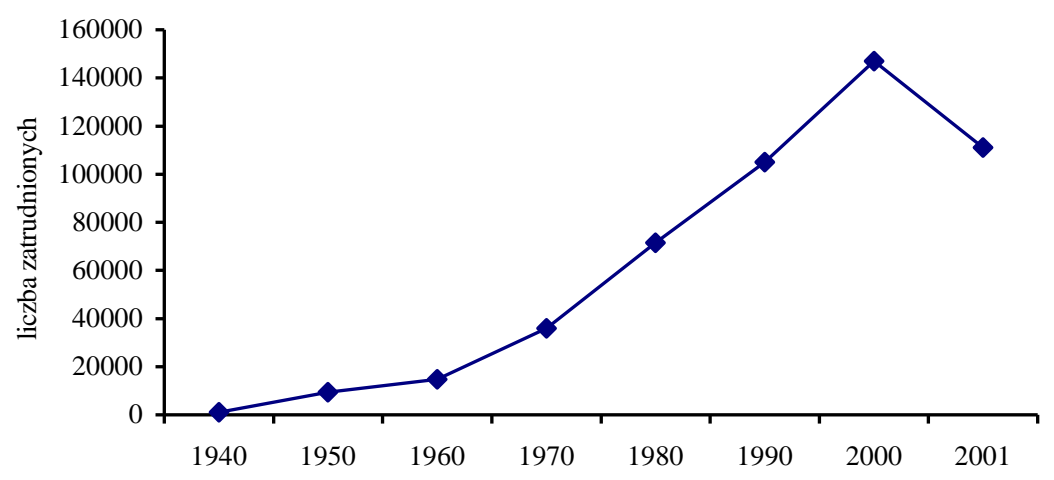

Ryc. 1. Zmiany w poziomie zatrudnienia Motoroli w latach 1940-2001

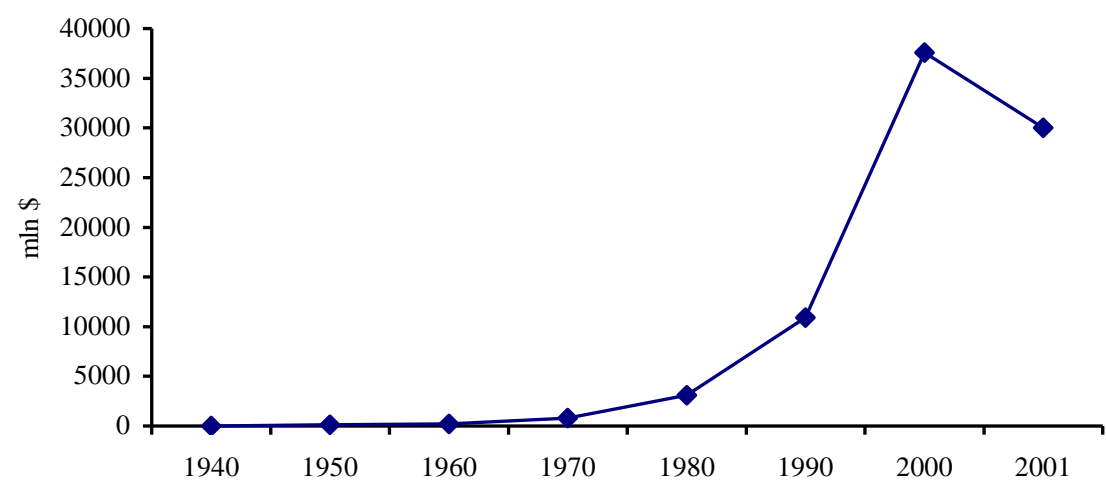

Ryc. 2. Zmiany w poziomie sprzedaży Motoroli w latach 1940-2001

W 1955 r. zapotrzebowanie rynku zmusza firmę do produkcji małych odbiorników zwanych "handie-talkie (kieszonkowy pager), wykorzystywanych w publicznych systemach komunikacyjnych w szpitalach i fabrykach.

Intensywny rozwój firmy powoduje, iż w 1967 r. Motorola przyłącza do swoich struktur organizacyjnych istniejące już fabryki tej branży w wielu różnych krajach, w tym w Australii, Francji, Hongkongu, Izraelu, Malezji, Meksyku, Puerto Rico, Południowej Korei, Tajwanie, Wielkiej Brytanii i wschodnich Niemczech.

Rozwój technologiczny przynosi kolejną zmianę w asortymencie. Motorola wypuszcza na rynek pierwszą kolorową telewizję tranzystorową Quasar. Rozwój firmy przejawia 
się wzrastającą sprzedażą, dochodem oraz liczbą zatrudnionych. W 1970 r. sprzedaż wyniosła $796 \mathrm{mln} \$$, a dochód $25 \mathrm{mln}$ \$, natomiast zatrudnienie wzrosło do 36 tys. osób.

Poważnym czynnikiem rozwoju Motoroli był rozwój przemysłu kosmicznego, zwłaszcza dziedzin związanych z przekazem informacji. W 1976 r. dzięki radiostacji wyprodukowanej przez Motorolę na Ziemię docierają pierwsze kolorowe fotografie powierzchni Marsa zrobione przez statek kosmiczny Viking 2. Na dalszy rozwój firmy wpływa rozwój przemysłu komputerowego. W 1979 roku przedstawiony zostaje pierwszy 16-bitowy mikroprocesor MC68000, a następnie pierwszy 32-bitowy mikroprocesor MC68020, zawierający 200 tys. tranzystorów. Ponadto Motorola zawiera technologiczne umowy z Apple Computer oraz IBM i wspólnie zaczynają badania nad nowym produktem PowerPC. W latach 90. Motoro-la angażuje się w przemysł telekomunikacyjny. W roku 1994 powstaje pierwszy komercyjny system radiostacyjny. Zostaje wyprodukowane radio sieciowe powstałe $z$ połaczenia komunikatorów głosowych, telefonów radiowych oraz systemu komunikacji danych. System ten nosi dziś nazwę iDEN® (Integrated Digital Enhanced Networks). Dzięki tej technologii uzyskać można natychmiastowy dostęp do potrzebnej informacji. Motorola jako pierwsza firma na rynku światowym sprzedaje w $2001 \mathrm{r}$. telefony z technologią GPRS (General Packet Radio Service). W wyniku prowadzenia systematycznych prac badawczo-rozwojowych i moni-torowania rynku Motorola wykorzystuje popularność serialu "Przyjaciele" i kreskówek "Looney Tunes", wprowadzając do swoich urządzeń dzwonki, gry i wygaszacze ekranu związane z bohaterami Warner Bross.

W wyniku przedstawionej analizy należy przyjąć, iż od 1940 r. Motorola rozwijała się dynamicznie. W dużej mierze rozwój ten zawdzięcza stale prowadzonym pracom badawczo-rozwojowym i obserwacji zmieniających się uwarunkowań na rynku globalnym. Przejawem tego rozwoju był szybki wzrost liczby zatrudnionych. W pierwszym dziesięcioleciu liczba pracujących osób wzrosła prawie 10-krotnie: z 935 osób w 1940 r. do 9325 osób w roku 1950. W latach 1950-2000 następuje ciąły wzrost liczby zatrudnionych: z 9,3 tys. do 147,0 tys., tj. ponad 15-krotnie. Po roku 2000 następuje spadek zatrudnienia do 111 tys., tj. o 24,5\%. Analizując zatrudnienie w Motoroli należałoby także zwrócić uwagę na odmienne tendencje w kształtowaniu się tego wskaźnika na terenie Stanów Zjednoczonych i poza obszarem państwa macierzystego (tab. 5).

Rozprzestrzenianie i rozwój firmy przyczyniał się do wzrostu zatrudnienia. I tak do roku 1997 ogólne zatrudnienie osiągnęło wartość 150,0 tys. osób, w 1999 r. uległo zmniejszeniu do 128,0 tys. Tak więc w pięcioletnim okresie ogólne zatrudnienie zmniejszyło się

o prawie $10 \%$. Z tą tendencją pokrywa się zatrudnienie na obszarze Stanów Zjednoczonych, przy czym zmniejszyło się ono o 27,4\%, osiągając w 1999 r. wielkość 57,2 tys.

Tabela 5. Zatrudnienie w Motoroli w latach 1995-1999

\begin{tabular}{|c|c|c|c|c|c|c|c|}
\hline \multirow[b]{2}{*}{ Lata } & \multicolumn{3}{|c|}{ Zatrudnienie } & \multirow{2}{*}{$\begin{array}{l}\% \text { udział zatrud- } \\
\text { nienia w filiach } \\
\text { zagranicznych }\end{array}$} & \multicolumn{3}{|c|}{ Dynamika } \\
\hline & ogółem & w USA & $\begin{array}{c}\text { filie } \\
\text { zagraniczne }\end{array}$ & & ogółem & w USA & $\begin{array}{c}\text { filie } \\
\text { zagraniczne }\end{array}$ \\
\hline 1995 & 142000 & 18 & 63200 & 44,5 & 100,0 & 100,0 & 100 \\
\hline 1996 & 139000 & 75262 & 63738 & 45,8 & 97,9 & 95,5 & 100,8 \\
\hline
\end{tabular}

* AOL Time Warner i Motorola zacieśniaja wspótpracę. www.motorola.pl 


\begin{tabular}{|l|r|r|r|r|r|r|l|}
\hline 1997 & 150000 & 80000 & 70000 & 46,7 & 105,6 & 101,5 & 110,8 \\
\hline 1998 & 141000 & 74200 & 66800 & 47,4 & 99,3 & 94,2 & 105,7 \\
\hline 1999 & 128000 & 57200 & 70800 & 55,3 & 90,1 & 72,6 & 112,0 \\
\hline
\end{tabular}

Źródło: Obliczenia własne na podstawie danych z World Investment Report i ze strony www.motorola.com

W latach 1995-1999 odmienną tendencję wykazywało zatrudnienie w filiach zagranicznych - wzrosło ono z 63,2 tys. do 70,8 tys., tj. o $12 \%$. Sytuacja ta spowodowana była przenoszeniem produkcji, otwieraniem nowych oddziałów na terenie Europy i Azji. Rynki te stały się bardziej chłonne i wykazywały większe zapotrzebowanie na produkty firmy. Wzrost zatrudnionych na tych terenach związany był także $\mathrm{z}$ występowaniem tu wyspecjalizowanej kadry oraz tańszej siły roboczej. W ten sposób obniżano koszty produkcji wykorzystując m.in. tańsze zasoby pracy, tańsze grunty pod budowę nowych oddziałów, a także obniżano koszty transportu gotowych już produktów.

Generalnie proces kształtowania się korporacji nawiązuje do postępującego procesu koncentracji kapitału oraz dążenia do podnoszenia swojej konkurencyjności. Rosnący bowiem potencjał kapitału wpływa na podnoszenie konkurencyjności danych produktów oraz sprzyja opanowywaniu już istniejących i tworzeniu nowych rynków zbytu. W zależności od postępujących zasobów kapitałowych zaznacza się proces przejmowania innych firm lub ich łączenia w bardziej złożone struktury organizacyjno-produkcyjne.

\section{STRUKTURA ORGANIZACYJNA KORPORACJI}

W wyniku procesu rozszerzania i doskonalenia produkcji oraz opanowywania nowych rynków zbytu nastąiła zmiana struktury organizacyjnej, której celem było dostosowanie jej do nowych uwarunkowań oraz podnoszenie konkurencyjności. W konsekwencji w strukturze wewnętrznej występuje podział na sektory zajmujące się wyspecjalizowaną działalnością, np. Sektor Półprzewodników SPS, zajmujący się produkcją i zbytem procesorów, Sektor Łączności Szerokopasmowej BCS, odpowiedzialny za systemy cyfrowe i systemy satelitarne, Sektor Komunikacji Osobistej PCS, którego zadaniem jest produkcja telefonów cyfrowych, krótkofalówek, oraz Sektor Rozwiązań Komercyjnych, Rządowych i Przemysłowych (ryc. 3).

Charakterystyczną cechą firm ponadnarodowych jest powstawanie ich filii na terenie innych miast, a także na terenie innych państw. Dotyczy to także firmy Motorola, która posiada swoje oddziały i filie na całym świecie. Obecnie wszystkie oddziały zlokalizowane są w 66 państwach, w 401 miastach świata. W strukturze korporacji wyodrębnionych jest 928 oddziałów i filii. Najwięcej oddziałów, bo aż 466 (co stanowi 50,2\% ogółu) zlokalizowanych jest na obszarze obu Ameryk. Kolejnym dużym skupieniem oddziałów firmy jest terytorium Azji i Oceanii gdzie znajdują się 244 oddziały (26,3\%). Trzecie miejsce pod względem występowania oddziałów firmy zajmuje Europa, gdzie swoją siedzibę ma 179 filii (19,3\%). Najmniejsza liczba oddziałów znajduje się na terenie Afryki, bo tylko $0,65 \%$.

Przestrzenny obraz występowania oddziałów Motoroli nawiązuje do poziomu rozwoju ekonomicznego oraz zasobów intelektualnych, które są podstawowym warunkiem rozwi- 
jania nowoczesnej produkcji przemysłowej. Duże zróżnicowanie występowania filii Motoroli zaznacza się na terenie poszczególnych państw. Na ich obszarze uwidacznia się zwarta lokalizacja występowania filii. Najliczniej oddziały korporacji występują w Stanach Zjednoczonych, gdzie w 152 miastach (co stanowi 88\% wszystkich miast) znajdują się 353 oddziały (tj. 38\%). Duża liczba oddziałów występuje także na obszarze Chin, gdzie w 23 miastach (tj. 5,7\%) zlokalizowano 42 oddziały. Podobnie na obszarze Izraela w 22 miastach (5,5\%) umiejscowionych jest 51 oddziałów, tj. 5,5\% (ryc. 4).

\section{MOTOROLA}

\begin{tabular}{|c|c|}
\hline $\begin{array}{l}\text { Sektor Półprzewodników } \\
\text { SPS }\end{array}$ & $\begin{array}{l}\text { Projektowanie, produkcja } \\
\text { sprzedaż procesorów }\end{array}$ \\
\hline $\begin{array}{l}\text { Sektor Lączności } \\
\text { Szerokopasmowej } \\
\text { BCS }\end{array}$ & $\begin{array}{l}\text { Systemy cyfrowe, kable i modemy } \\
\text { Zakończenia systemowe CMTS } \\
\text { Cyfrowe systemy telewizji satelitarnej } \\
\text { Domowe satelity sieciowe }\end{array}$ \\
\hline $\begin{array}{l}\text { Sektor Komunikacji } \\
\text { Osobistej } \\
\text { PCS }\end{array}$ & $\begin{array}{l}\text { Wyposażenia radiowe } \\
\text { Radia przenośne } \\
\text { Telefony cyfrowe iDEN } \\
\text { Krótkofalówki }\end{array}$ \\
\hline $\begin{array}{l}\text { Sektor Rozwiązań } \\
\text { Komercyjnych, } \\
\text { Rządowych } \\
\text { i Przemysłowych }\end{array}$ & $\begin{array}{l}\text { Analogowe i dwuzakresowe } \\
\text { radioodtwarzacze }\end{array}$ \\
\hline $\begin{array}{l}\text { Sektor Rozwiązań } \\
\text { Teleinformatycznych } \\
\text { i Internetu }\end{array}$ & $\begin{array}{l}\text { Przemysłowe systemy elektroniczne } \\
\text { Produkty komputerowe }\end{array}$ \\
\hline $\begin{array}{l}\text { Sektor } \\
\text { Rozwiązań }\end{array}$ & Systemy komunikacji radiowej \\
\hline Inne & $\begin{array}{l}\text { Inne (Corporate), IESS, Światowe } \\
\text { Centrum Rozwiązań, Global Software } \\
\text { Group, Uniwersytet, Sektor Rozwiązań } \\
\text { NSS, Przedsiębiorstwo Komunikacyjne }\end{array}$ \\
\hline
\end{tabular}

Ryc. 3. Struktura organizacyjna Motoroli wg sektorów w $2001 \mathrm{r}$.

Źródło: Opracowanie własne na podstawie danych ze strony www.motorola.com

W Europie najliczniej oddziały Motoroli zlokalizowane są w Wielkiej Brytanii: 34 oddziały $(3,7 \%)$ w 18 miastach (4,5\%). Podobna sytuacja jest na terenie Niemiec, gdzie w 17 miastach (tj. 4,2\%) znajdują się 33 oddziały, tj. 3,6\% (ryc. 5). Stosunkowo duża koncentracja oddziałów rożnych sektorów występuje na terenie Australii, Kanady, Meksyku, Francji i Japonii. Ogółem na terenie wymienionych 10 państw zlokalizowanych jest 648 oddziałów, co stanowi 70\% wszystkich oddziałów Motoroli. Oddziały te występują w 377 miastach, tj. 94\% wszystkich miast. Na terenie 55 pozostałych państw zlokalizowano $30 \%$ oddziałów firmy.

W strukturze wewnętrznej firmy sektorem posiadającym najwięcej oddziałów - 182, co stanowi 19,6\% - jest sektor CGIS Sektor Rozwiązań Komercyjnych, Rządowych i Przemysłowych; jego oddziały znajdują się na terenie Stanów Zjednoczonych (75), Izraela (38), Australii (10), Kanady (7), Niemiec (5) i Wielkiej Brytanii (4). Najbardziej atrakcyjne dla lokalizacji tego typu oddziałów są wschodnie tereny Stanów Zjednoczonych, 
najbardziej rozwinięte gospodarczo. Na tych obszarach istnieje bezpośredni popyt na produkty tego sektora. Najwięcej oddziałów zlokalizowanych jest w Schaumburgu (6 oddziałów),

w mieście gdzie znajduje się siedziba i zarząd firmy. Pięć oddziałów znajduje się w zachodniej części kraju w San Diego (ryc. 6). Po trzy oddziały zlokalizowano w Irvine, Los Angeles

i Scottsdale. Kolejnym miejscem skupienia oddziałów Sektora Rozwiązań Komercyjnych, Rządowych i Przemysłowych jest Izrael. Oddziały te skupione są głównie w centralnej części kraju, przy czym najliczniej występują one w stolicy państwa Tel Avivie (ryc. 7).

Dużą liczbę oddziałów sektora CGISS zlokalizowano na obszarze Australii. Znajduje się tu 10 oddziałów w 9 miastach. Skupiają się one głównie w południowo-wschodniej części kraju w dominujących ośrodkach miejskich, takich jak: Sydney, Canberra, Melbourne. Kolejne skupienie oddziałów tego sektora występuje w Kanadzie, gdzie zlokalizowano

7 oddziałów w 7 miastach. Największe zagęszczenie znajduje się w południowo-wschod-niej części kraju w sąsiedztwie większych ośrodków miejskich położonych blisko granicy ze Stanami Zjednoczonymi. Warto tu także wspomnieć o państwach europejskich, takich jak Niemcy i Wielka Brytania. Na obszarze Niemiec znajduje się 5 oddziałów sektora CGISS w 4 miastach: Hamburgu, Berlinie, Eschborn i Taunusstein. W Wielkiej Brytanii zlokalizowano 4 oddziały w dwóch miastach: Hants i Bathgate (ryc. 8).

Obok wyróżnionych skupień Sektor Rozwiązań Komercyjnych, Rządowych i Przemysłowych ma swoje siedziby w innych krajach, głównie w stolicach państw: Puerto Rico, Bogocie, Santiago, Buenos Aires, Rijadzie, Bangkoku, Seulu, Tokyo, Dżakarcie oraz Auckland, a także w znaczących aglomeracjach, takich jak Alberta czy Perth. Koncentracja tego typu oddziałów związana jest głównie ze stolicami państw, gdzie mieszczą się struktury rządowe

i decyzyjne, będące głównymi odbiorcami oferowanych przez firmę produktów.

Kolejnym ważnym sektorem jest Sektor Półprzewodników SPS posiadający 159 oddziałów, tj. 17,1\%; jego filie znajdują się na terenie Stanów Zjednoczonych (59), Meksyku (9), Japonii (9), Chin (8), Niemiec (7), Kanady (6) (ryc. 9). Najwięcej oddziałów tego sektora zlokalizowanych jest na obszarze Stanów Zjednoczonych - w 43 miastach występuje 59 oddziałów. Najwięcej filii (5 oddziałów) zlokalizowano w Austin.

Innym większym skupiskiem jest obszar Japonii, gdzie w pięciu miastach: Osace, Tokyo, Sendai, Chibie i Nagoi zlokalizowano 9 oddziałów sektora SPS. Przyczyną koncentracji oddziałów tego sektora jest rozwijający się na tym obszarze przemysł wysokich technologii, zasilający rynek globalny produktami komputerowymi i radiowymi. Sektor SPS znalazł na tym obszarze wielu odbiorców dla swoich produktów. Podobne czynniki przyczyniły się do dużego zagęszczenia oddziałów Sektora Półprzewodników w Chinach, gdzie w 7 miastach (m.in. w Pekinie, Szanghaju, Leshan) zlokalizowano 8 oddziałów. Poza Azją Wschodnią dużym skupieniem oddziałów sektora SPS charakteryzuje się Meksyk, na terenie którego w 7 miastach zlokalizowano 8 oddziałów. W Europie najwięcej oddziałów

(7 filii) omawianego sektora zlokalizowano w 7 miastach niemieckich, m.in. w Berlinie, Dreźnie, Frankfurcie n/Odrą, Norymbergii i Monachium (ryc. 10).

Największą grupe, skupiającą 381 oddziałów, tj. 41,05\% stanowią sektory Inne, w skład których weszły m.in. Sektor Rozwiązań Internetowych NSS i Przedsiębiorstwo Komunikacyjne.

Kolejnym ważnym sektorem jest Sektor Corporate posiadający 137 oddziałów w 46 państwach, w 93 miastach (ryc. 11). Najwięcej oddziałów tego sektora zlokalizowanych 
jest na terenie Stanów Zjednoczonych (w 16 miastach 40 oddziałów). Najwięcej filii występuje w Schaumburgu (11), Austin (5) i w Phoenix (4). Następnym większym skupieniem jest obszar Australii, na terenie której w 10 miastach znajduje się 12 oddziałów tego sektora. Trzecim skupiskiem są Chiny, głównie Chiny Środkowo-Wschodnie, gdzie w 8 miastach (m.in. Shangaju, Changsha, Chonqoing, Chengdu, Zhengzhou, Dalian) znajduje się 10 oddziałów. Oddziały tego sektora zlokalizowane są głównie w stolicach poszczególnych państw (San Jose, Puerto Rico, Bogota, Lima, Brasil, Buenos Aires, Santiago, Rabat, Kair, Rijad, Tel Aviv, Amsterdam, Paryż, Bratysława, Warszawa, Ryga, Wilno, Mińsk, Moskwa, Hanoi, Dżakarta, Kuala Lumpur, Seul, Tokyo, Taipei).

Oddziały sektora Przedsiębiorstwo Komunikacyjne (Communications Enterprise) znajdują się w 22 państwach, w 73 miastach (ryc. 12). Prawie 50\% wszystkich oddziałów tego sektora znajduje się na terenie Stanów Zjednoczonych (42 oddziały). Pozostałe większe skupiska to Chiny (5 oddziałów w miastach: Jinan, Hangzhou, Xi'an) (ryc. 13) i Meksyk, gdzie również znajduje się 5 oddziałów. Duże skupisko oddziałów tego sektora znajduje się także w Europie. W Wielkiej Brytanii zlokalizowano 5 oddziałów, a na terenie Niemiec 4. Oddziały tego sektora zlokalizowane są także w stolicach państw, np. w Puerto Rico, Quito, Singapurze, Taipei, Tokyo, Sydney.

Kolejnym sektorem jest Sektor Komunikacji Osobistej, którego oddziały zlokalizowano w 37 państwach, w 74 miastach (ryc. 14). Najwięcej oddziałów znajduje się na terenie Stanów Zjednoczonych (24 filie zlokalizowane w 20 miastach - ryc. 15). Kolejny obszar zagęszczenia tymi oddziałami to Azja Południowo-Wschodnia (m.in. Chiny, Tajwan, Japonia, Korea Południowa, Indonezja, Hongkong), gdzie znajduje się 18 oddziałów Sektora PCS. Trzecim obszarem występowania tych filii jest Europa, w szczególności Europa Zachodnia (4 oddziały

w Wielkiej Brytanii, 2 oddziały na terenie Niemiec, Włoch i Szwecji).

Innym sektorem dominującym pod względem liczby oddziałów jest Sektor Powiązań NSS (Networking Solutions Sector). Jego oddziały zlokalizowane są w 28 państwach i 67 miastach świata. Największa koncentracja występuje na obszarze Stanów Zjednoczonych, gdzie znajduje się 37 oddziałów w 30 miastach (ryc. 16). Innym regionem koncentracji tych oddziałów jest Japonia, na obszarze której w 6 miastach zlokalizowanych jest 8 oddziałów, a także Korea Południowa, gdzie w 3 miastach zlokalizowano 4 filie.

W Europie oddziały sektora NSS nie wykazują większej koncentracji. Poza wymienionymi ośrodkami lokalizacji, oddziały te występują także w stolicach państw.

Pozostałe sektory posiadają niewiele oddziałów. Należy jednak zwrócić uwagę, że na terenie Stanów Zjednoczonych nie występują żadne oddziały Global Software Group.

Dla funkcjonowania Motoroli powstały na świecie także szkoły wyższe. W Stanach Zjednoczonych w Arlington (ryc. 17) znajduje się jeden uniwersytet Motoroli, pozostałe są w Johannesburgu (Republika Południowej Afryki), w Tokyo (Japonia) i w Mediolanie (Włochy) (ryc. 18, 19).

Najwięcej oddziałów z pozostałych sektorów posiada Sektor Łączności Szerokopasmowej (BCS) oraz Sektor IESS (Integrated Electronic Systems Sector). W Europie znajduje się większość oddziałów sektora ING (Internet and Networking Group), zlokalizowanych w strefie od Londynu przez Belgię i zachodnie Niemcy aż po Mediolan.

W Europie znajduje się jeden z trzech występujących na świecie sektorów Global Soft-ware Group, zlokalizowany w Polsce. Motorola w Polsce zaczęła swoją działalność w 1992 r. Zajmuje się produkcją i dystrybucją produktów związanych z komunikacją. Obec- 
nie w polskiej Motoroli pracuje 200 osób . Firma posiada w Polsce dwa oddziały: w Warszawie

i w Krakowie. Krakowskie Centrum Oprogramowania powstało w 1998 r. Projektuje się tu oprogramowanie dla systemów telekomunikacyjnych, sieci Web i narzędzi inżynierii oprogramowania systemów łączności dla służb bezpieczeństwa publicznego i Internetu.

$\mathrm{Z}$ powyższej analizy wynika, iż filie reprezentujące poszczególne sektory skoncentrowane są głównie na obszarze Stanów Zjednoczonych (38\% wszystkich oddziałów Motoroli), Izraela (5,5\%), Chin (4,5\%), Wielkiej Brytanii $(3,7 \%)$, Niemiec $(3,6 \%)$, a także na terenie Australii (3,6\%) i Kanady (3,4\%). Łącznie skupia się tu ponad połowa $(52,3 \%)$ ogólnej liczby filii tej korporacji.

ryc. 4

* www.gazeta.pl 
ryc. 5 
Ryc. 6 
Ryc. 7. Lokalizacja oddziałów Motoroli w Izraelu w $2001 \mathrm{r}$.

Źródło: Opracowanie własne na podstawie jednostkowych danych (Wajda 2002)

ryc. 8 
ryc. 9 
ryc. 10 
ryc. 11 
ryc. 12 
ryc. 13 
ryc. 14 
ryc. 15 
ryc. 16 
ryc. 17 
ryc. 18 
ryc. 19 
W świetle przedstawionej analizy dotyczącej rozwoju korporacji, jej zmian finansowych, strukturalnych i przestrzennych można powiedzieć, iż korporacje transnarodowe są ważnym ogniwem procesu globalizacji. Głównym czynnikiem rozwoju jest podejmowanie nowoczesnej produkcji opartej na wiedzy oraz lokalizacja oddziałów produkcyjnych najczęściej na obszarze rynków zbytu, z wykorzystywaniem tanich zasobów produkcyjnych.

Proces intensywnego rozwoju Motoroli obejmuje zaledwie 22 lata; swą działalnością objęła ona w zasadzie wszystkie wiodące centra gospodarcze świata. Dzięki podejmowaniu nowoczesnej produkcji gwałtownie wzrosła liczba ośrodków lokalizacji oddziałów Motoroli - 928 oddziałów zlokalizowanych jest w 401 miastach i w 66 państwach.

Podstawową funkcję w strukturze Motoroli odgrywają sektory, wśród których największy dochód w 2001 r. przyniósł Sektor Półprzewodników (30,35\% dochodu korporacji) oraz Sektor Rozwiązań Sieciowych (18,65\%) i Sektor Komunikacji Osobistej $(17,89 \%)$ (tab. 6). Te trzy sektory w sumie przynoszą prawie $67 \%$ ogólnego dochodu całej korporacji. Najwięcej udziałów w sprzedaży firmy miały w 2001 r. Sektor Komunikacji Osobistej (34,8\%), Sektor Rozwiązań Sieciowych (21,8\%), Sektor Półprzewodników (16,4\%) i Sektor Rozwiązań Komercyjnych, Rządowych i Przemysłowych (14,4\%). Łącznie wartość wymienionych sektorów obejmowała 87,4\% ogólnej wartości sprzedaży całej korporacji.

Tabela 6. Struktura potencjału sektorów Motoroli w 2001 roku

\begin{tabular}{|l|c|c|}
\hline \multicolumn{1}{|c|}{ Sektor } & Dochód & Sprzedaż \\
\hline Sektor Półprzewodników & $30,35 \%$ & $16,4 \%$ \\
\hline GTSS & $18,65 \%$ & $21,8 \%$ \\
\hline Sektor Komunikacji Osobistej & $17,89 \%$ & $34,8 \%$ \\
\hline BCS & $13,65 \%$ & $9,5 \%$ \\
\hline $\begin{array}{l}\text { Sektor Rozwiązań Komercyjnych } \\
\text { Rządowych i Przemysłowych }\end{array}$ & $8,33 \%$ & $14,4 \%$ \\
\hline Inne & $7,35 \%$ & $2,8 \%$ \\
\hline ING & $4,5 \%$ & $7,6 \%$ \\
\hline Korporacja ogółem & $100 \%$ & $100 \%$ \\
\hline
\end{tabular}

Źródło: Obliczenia własne na podstawie danych pochodzących z oficjalnej strony Motoroli: www.motorola.com

Reasumując należy przyjąć, że poszczególne sektory charakteryzują się odmiennymi tendencjami w zakresie lokalizacji przestrzennej. Sektor Rozwiązań Komercyjnych, Rządowych i Przemysłowych koncentruje się przeważnie w Stanach Zjednoczonych, w Izraelu, Australii i w Europie. Sektor Półprzewodników skupia się w Stanach Zjednoczonych, w Azji Południowo-Wschodniej, w Meksyku i w Europie. Większość sektorów wykazuje tendencje do lokalizacji w stolicach państw lub w wielkich aglomeracjach. Charakterystyczne dla lokalizacji jest skupianie się sektorów w strefach intensywnego rozwoju. Można wymienić trzy centra koncentracji oddziałów Motoroli; są to: Stany Zjednoczone, Azja Południowo-Wschodnia i Europa. Do lokowania działalności produkcyjnej na terenie Azji poza dostępem do rynków zbytu skłaniają także zasoby taniej siły roboczej, prowadzące do obniżania kosztów produkcji. Należy się także spodziewać, iż proces rozwoju wysokiej 
techniki doprowadzi do dalszej polaryzacji świata i poszczególnych krajów oraz zaostrzy sprzeczności i doprowadzi do jeszcze wyraźniejszego podziału regionów (Zioło 2001).

Wydaje się, iż znajomość mechanizmów funkcjonowania firm ponadnarodowych ma duże znaczenie dla naszego kraju. Należy przyjąć, iż w najbliższych latach obszar ten w coraz większym stopniu będą penetrować korporacje ponadnarodowe pod katem poszukiwania tanich miejsc lokalizacji swoich oddziałów, w poszukiwaniu taniej i wykształconej siły roboczej, dążąc w ten sposób do obniżania kosztów pracy, a także w poszukiwaniu potencjalnych rynków zbytu dla swoich produktów. Warto tu zauważyć, iż - jak wynika z danych Price Waterhouse Coopers - w ciagu ostatnich lat w Polsce o ponad 50\% wzrasta liczba przejęć i fuzji. Należy podkreślić, iż zwiększa się aktywność inwestorów zagranicznych ze Stanów Zjednoczonych, Niemiec i Wielkiej Brytanii oraz korporacji transnarodowych. Porównując listę stu największych korporacji działających na świecie z listą największych inwestorów zagranicznych w Polsce zauważamy, że ponad trzydzieści firm spośród największych koncernów ponadnarodowych obecnie działa już w Polsce (Durka 2000).

W świetle procesu globalnego należy wnioskować, iż przestrzenne powiązania sieciowe nasilać się będą w skali globalnej i obejmować będą nowe obszary, w tym także Polskę. Konieczne staje się wiec podejmowanie działań zmierzających do podnoszenia atrakcyjności tych regionów dla lokalizacji interesujących nas sektorów produkcyjnych.

\section{Literatura}

“Business Week" 1990, 1996, 1997, 1998, 1999, 2000, 2001

"Business Week Polska" 2002

Durka B., 2000, Działalność korporacji międzynarodowych na świecie $i$ w Polsce, [w:] Inwestycje zagraniczne w Polsce. Raport jubileuszowy, IKiCHZ, Warszawa

Dytwald J.A., 1997, Wspótczesne koncepcje zarzqdzania korporacjami, Warszawa

Gwiazda A., 1998, Globalizacja i regionalizacja gospodarki światowej, Toruń

Mydel R. (red.), 2000, Popularna encyklopedia powszechna. Kontynenty i państwa. Europa, T. 1, Kraków

Sporek T., 1998, Zagraniczne inwestycje bezpośrednie głównq strategiq korporacji transnarodowych, Katowice

Wajda E., 2002, "Proces kształtowania się ponadnarodowych firm na przykładzie Motoroli”, praca magisterska wykonana w Zakładzie Przedsiębiorczości i Gospodarki Przestrzennej Instytutu Geografii Akademii Pedagogicznej w Krakowie, pod kierunkiem prof. Z. Zioło

Wojciechowski H., 2000, Przedsiębiorstwo transnarodowe w procesach globalizacyjnych, [w:] Przedsiębiorstwo a internacjonalizacja działalności gospodarczej, Zeszyty Naukowe AE w Poznaniu, seria T, zeszyt 278

World Investment Report 1996, 1997, 1998, 1999, 2000

Zioło Z., 2001a, Wspótczesne tendencje rozwoju przemystu i ich problematyka badawcza, [w:] Problematyka przemian struktur przestrzennych przemystu, Prace Komisji Geografii Przemysłu PTG nr 2, Kraków

Zioło Z., 2001b, Struktura branżowa i koncentracja przestrzenna wiodacych światowych firm przemysłowych, [w:] Problemy przemian struktur przemystowych w procesie wdrażania regut gospodarki rynkowej, Prace Komisji Geografii Przemysłu PTG nr 3, Kraków

Zorska A., 1996, Przemiany organizacyjne w korporacjach transnarodowych, "Przegląd Organizacji” nr 3 
Zorska A., 2000a, Korporacje transnarodowe, [w:] Biznes międzynarodowy - obszary decyzji strategicznych, pod red. M.K. Nowakowskiego, Warszawa

Zorska A., 2000b, Ku globalizacji? Przemiany $w$ korporacjach transnarodowych $i$ gospodarce światowej, Warszawa 